\title{
Natural occurrence of nivalenol in foods
}

\author{
Takumi YoshIZAWA*
}

芳澤 宅實*：ニバレノールによる食品污染

Isolation of nivalenol (NIV) from Fusarium nivale Fn-2B and its structural elucidation were reported in 1968 to $1970^{1-3)}$. Thereafter deoxynivalenol (DON) was discovered, and its natural occurrence with NIV was firstly confirmed in 1972 to $1973^{4,5}$. Since these findings, more than a quarter century has passed, and thousands of papers related to these mycotoxins have been published. The two trichothecenes are produced mainly by $F$. graminearum Schwabe (telemorph Gibberella zeae (Schw.) Petch.), one of the major causative phytopathogens of head blight disease in wheat and barley and rot disease in corn, and occur worldwide in these plant products intended for human and animal consumption ${ }^{6-8)}$.

Besides many published surveys for trichothecenes in foods, informations on the worldwide occurrence of NIV are limited, especially compared with DON, and how common it is and what significance it has for human and animal health are still not clear. Table 1, cited from IARC Monographes ${ }^{8)}$ with modifications, shows the worldwide occurrence of NIV in cereals. NIV has been reported extensively in Japanese and Korean grain samples, and concentrations up to 22.9 $\mu \mathrm{g} / \mathrm{kg}$ have been found in Japanese cereals and $3.0 \mu \mathrm{g} / \mathrm{kg}$ in wheat from Korea. It has also been reported at relatively low levels in samples from Europe, southern Africa and Australia, whereas it is virtually unknown in grains in North and South America. Thus, there seems to be a

Table 1 Worldwide occurrence of nivalenol in cereals*.

\begin{tabular}{llccc}
\hline \hline Country or region & Product & Year & $\begin{array}{c}\text { Positive/ } \\
\text { total no. }\end{array}$ & $\begin{array}{c}\text { Content } \\
(\mathrm{mg} / \mathrm{kg})\end{array}$ \\
\hline Argentina & Cereals & 1983 & $15 / 60$ & Mean, 0.03 \\
Norway & Barley, wheat & 1984 & $102 / 102$ & $0.01-0.25$ \\
Poland & Wheat & 1985 & $43 / 48$ & $0.003-0.35$ \\
United Kingdom & Wheat, barley & 1984 & $20 / 39$ & $0.004-1.1$ \\
Transkei (S. Africa) & Maize & 1985 & $44 / 96$ & $0.01-15.2$ \\
China & Wheat & 1989 & $7 / 30$ & $0.01-0.02$ \\
& Wheat & $\mathrm{NR}$ & $45 / 49$ & Mean, 0.04 \\
Japan & Wheat & 1984 & $7 / 18$ & $0.05-0.44$ \\
& Barley & $1970-80$ & $73 / 89$ & $0.06-22.9$ \\
Korea & Wheat, barley & $1983-87$ & $85 / 87$ & $0.02-3.0$ \\
Taiwan & Wheat, barley & $1984-85$ & $14 / 26$ & $0.005-0.98$ \\
\hline
\end{tabular}

* Cited from ref. 8.

* Department of Bioresource Science, Faculty of Agriculture, Kagawa University, Miki-cho (Kagawa 761-07)

香川大学農学部生物資源科学科（テ761-07 香川県木田郡三木町） 
Table 2 Occurrence of NIV and DON in Japanese wheat and barley grains (1989-1994).

\begin{tabular}{cccc}
\hline \hline & Total & Wheat & Barley \\
\hline No. samples analyzed & 245 & 151 & 94 \\
No. positive & 190 & 108 & 82 \\
(\%) & $(78)$ & $(72)$ & $(87)$ \\
NIV positive & 178 & 100 & 78 \\
(\%) & $(73)$ & $(66)$ & $(83)$ \\
DON positive & 153 & 82 & 71 \\
(\%) & $(62)$ & $(54)$ & $(76)$ \\
NIV + DON & 144 & 75 & 69 \\
(\% positive) & $(76)$ & $(69)$ & $(84)$ \\
NIV concentration, & & 136 & 218 \\
mean (range), ng/g & & $(5-4,390)$ & $(15-3,900)$ \\
DON concentration, & & 162 & 270 \\
mean (range), ng/g & & $(5-1,620)$ & $(5-3,780)$ \\
\hline
\end{tabular}

geographical difference in the NIV occurrence, whereas DON occurs worldwide in cereals of temperate regions ${ }^{8)}$. Moreover, NIV has been found in corn from the Philippines even though at low levels ${ }^{9}$, indicating the probably wide distribution of NIV not only in temperates but also in tropics. Further efforts should be made to gain an appreciation of global aspect of the natural occurrence of NIV.

In Japan, DON and NIV are two major trichothecenes coincidentally occurring in domestic wheat and barley grains ${ }^{10}$. Recently, comprehensive studies on the geographic difference in the trichothecene occurrence and the distribution of toxigenic $G$. zeae (F. graminearum) in wheat and barley have been conducted in the author's laboratory ${ }^{11-13)}$. A total of 245 grain samples (151 wheat and 94 barley grains) were collected in 1984 to 1994 from 88 fields in 16 prefectures and analyzed for trichothecenes by GC-MS according to the previously reported procedure ${ }^{12}$. As summarized in Table 2, the trichothecenes were detected in 190 (78\%) samples; NIV and DON were in 178 and 153 samples, respectively, and 144 samples were co-contaminated with both toxins. Analytical results indicated a regional difference in the DON and NIV contamination of Japanese wheat and barley. DON was the major trichothecene in the northern districts, Akita and Hokkaido (approximately 70\% DON in concentration) and NIV in the central districts (over $80 \%$ NIV), whereas in the southern districts the DON levels was 30 to $50 \%$ in Shikoku district, and was slightly higher (55 to $65 \%$ ) than the NIV level in Kyushu district. Several data ${ }^{14-17)}$ previously obtained in Hokkaido, Kanto and Hokuriku districts were in line with the results obtained in this study. These results on the occurrence of NIV and DON were highly correlated to the geographic difference in the distribution of different chemotypes of Fusarium (Gibberella) species producing these trichothecenes in wheat and barley and also in fields of these crops in Japan.

Table 3 presented the natural co-occurrence of DON and NIV together with their acetylated derivatives in selected grain samples from different regions ${ }^{12}$. $3-\mathrm{ADON}$ occurred together with 
Table 3 Natural co-occurrence of trichothecenes (DON, NIV and their acetylated derivatives) and ZEA in Japanese wheat and barley grains.

\begin{tabular}{|c|c|c|c|c|c|c|c|c|}
\hline \multirow{2}{*}{ Prefecture } & \multirow{2}{*}{$\begin{array}{l}\text { Crop } \\
\text { year }\end{array}$} & \multirow{2}{*}{$\begin{array}{l}\text { Cereal } \\
\text { type }\end{array}$} & \multirow{2}{*}{$\begin{array}{l}\text { Sample } \\
\text { code }\end{array}$} & \multicolumn{5}{|c|}{ Concentration of mycotoxin, ng/g } \\
\hline & & & & DON & $3 \mathrm{ADON} / 15 \mathrm{ADON}^{*}$ & NIV & 4-ANIV & ZEA \\
\hline \multirow[t]{3}{*}{ Hokkaido } & 1990 & wheat & 9067 & 323 & $\operatorname{tr}$ & 22 & - & - \\
\hline & 1991 & wheat & 9141 & 1,510 & $10^{*}$ & 117 & - & - \\
\hline & & & 9176 & 664 & $11 / \operatorname{tr}^{*}$ & 41 & - & - \\
\hline \multirow[t]{3}{*}{ Akita } & 1990 & barley & 9055 & 6,120 & $437 / 522^{*}$ & 729 & 171 & - \\
\hline & & & 9058 & 307 & 10 & 498 & 60 & - \\
\hline & & & 9059 & 997 & $65 / 96^{*}$ & 254 & $\operatorname{tr}$ & - \\
\hline Tochigi & 1990 & wheat & 9020 & 29 & - & 367 & $\operatorname{tr}$ & - \\
\hline \multirow[t]{2}{*}{ Kyoto } & 1990 & barley & 9027 & 467 & 161 & 2,860 & 215 & 105 \\
\hline & & & 9028 & 3,330 & 347 & 20,300 & 462 & 159 \\
\hline \multirow[t]{2}{*}{ Kagawa } & 1990 & barley & 9012 & 653 & 112 & 878 & - & - \\
\hline & & wheat & 9013 & 368 & 41 & 645 & - & - \\
\hline \multirow[t]{2}{*}{ Ehime } & 1989 & barley & 8904 & 448 & 85 & 226 & 57 & - \\
\hline & & & 8915 & 418 & 93 & 116 & $\operatorname{tr}$ & - \\
\hline \multirow[t]{3}{*}{ Fukuoka } & 1991 & wheat & 9134 & 11,700 & 920 & 4,390 & - & 505 \\
\hline & & barley & 9135 & 70,500 & 18,700 & 26,000 & - & 11,500 \\
\hline & & & 9136 & 61,200 & 11,000 & 14,100 & 2,470 & 15,300 \\
\hline \multirow[t]{3}{*}{ Oita } & 1991 & wheat & 9122 & 698 & 108 & 475 & - & 459 \\
\hline & & barley & 9124 & 2,460 & 210 & 1,170 & - & 661 \\
\hline & & & 9125 & 752 & 170 & 668 & 87 & - \\
\hline
\end{tabular}

* Concentration of $15-\mathrm{ADON}$. $\mathrm{tr}$ : below $10 \mathrm{ng} / \mathrm{g}$.

DON in almost all prefectures, whereas $15-\mathrm{ADON}$ was found mainly in the samples from northern prefectures, Hokkaido and Akita. These results may support the geographic difference in the distribution of different DON-chemotypes of $F$. graminearum. The presence of monoacetylated DON in cereal grains may be considered as an indication of the subclassified DON-producers involved in the field infection of cereals. On the other hand, the occurrence of 4-ANIV seems to be less frequent than that of 3-ADON, but it was found in most prefectures except Hokkaido and Kagawa. These results on the different profile on the occurrence of several trichothecenes are clearly correlated to the geographic difference in the distribution of different chemotypes of $F$. graminearum (3-ADON producer, 15-ADON producer and NIV producer) in Japan. In addition to the co-occurrence of DON and NIV, the presence of their acetylated toxins is of importance because they have been found in both feeds associated with field outbreaks of animal mycotoxicoses ${ }^{18)}$ and staple foods collected from high-risk areas of human chronic diseases ${ }^{19-21)}$. Furthermore, the estimated acute toxicities of the monoacetylated derivatives are greater than the parent toxins ${ }^{22,23)}$. Therefore, more attention should be devoted to the natural occurrence of these acetylated trichothecenes together with DON and NIV and the combined effects of these toxins on human and animal health.

With regard to the occurrence of NIV in commercial foods, it was detected togeteher with DON in commercial parched barley flour (Mugi-kogashi or hattaiko, in Japanese) ${ }^{24)}$, which had been reported to be associated with a human intoxication. A similar situation in the contamination of trichothecenes in domestic foodstuffs can be pointed out from the data of surveys carried 
out by other groups ${ }^{25,26}$. However, informations on NIV in foods are limited compared with DON, which is frequently found in foodstuffs for human consumption in several countries ${ }^{7,27,28)}$. Since these informations are important to assess the human exposure and the possible risk to human health, much efforts should be made to clarify this point for NIV.

\section{References}

1) Tatsuno, T., Saito,, M., Enomoto, M., Tsunoda, H.: Chem. Pharm. Bull., 16, 2519 (1968).

2) Tatsuno, T., Fujimoto, Y., Morita, Y.: Tetrahedron Lett., 33, 2823 (1969).

3) Ueno, Y., Ishikawa, Y., Saito-Amakai, K., Tsunoda, H.: Chem. Pharm. Bull., 18, 304 (1970).

4) Morooka, N., Uratsuji, N., Yoshizawa, T., Yamamoto, H.: J. Food Hyg. Soc. Jpn., 13, 368 (1972).

5) Yoshizawa, T., Morooka, N.: Agric. Biol. Chem., 37, 2933 (1973).

6) WHO: "Environmental Health Criteria No. 105, Selected Mycotoxins: Ochratoxins, Trichothecenes, Ergot," p. 71 (1990), WHO, Geneva.

7) Yoshizawa, T.: "Mycotoxins and Animal Foods" (Smith, J. E. and Henderson, R. S. ed.), p. 301 (1991), CRC Press, Florida.

8) IARC "IARC Monographs on the Evaluation of Carcinogenic Risks to Humans Vol. 56, Some Naturally Occurring Substances: Food Items and Constituents, Heterocyclic Aromatic Amines and Mycotoxins," p. 397, 467 (1993), IARC, Lyon.

9) Yamashita, A., Yoshizawa, T., Aiura, Y., Sanchez, P. C., Dizon, E. I., Sardjono : Biosci. Biotech. Biochem., 59, 1804 (1995).

10) Yoshizawa, T.: “Trichothecenes-Chemical, Biological and Toxicological Aspects” (Ueno, Y. ed.), p. 195 (1983), Elsevier, Amsterdam.

11) Jin, Y. Z. : Doctoral Dissertation, United Grad. Schl. Agric. Sci. Ehime Univ. (1995).

12) Yoshizawa, T., Jin, Y. Z.: Food Add. Contam., 12, 689 (1995).

13) Yoshizawa, T.: Bull. Inst. Compr. Agric. Sci. Kinki. Univ., 5, 23 (1997).

14) Dohi, Y., Watanugi, F., Kitai, H., Kosaka, K., Ichinoe, M., Ohba, K. : J. Food Hyg. Soc. Jpn., 25 : 1 (1984).

15) Tanaka, T., Hasegawa, A., Matsuki, Y., Ishii, K., Ueno, Y.: Food Add. Contam., 2, 125 (1985).

16) Tanaka, T., Hasegawa, A., Matsuki, Y., Matsui, Y., Lee, U. S., Ueno, Y.: J. Food Hyg. Soc. Jpn., 26, 519 (1985).

17) Fujisawa, T., Mori, M., Ichinoe, M.: Proc. Jpn. Assoc. Mycotoxicol., 35, 37 (1992).

18) Abbas, H. K., Mirocha, C. J., Tuite, J.: Appl. Environ. Microbiol., 51, 841 (1986).

19) Hsia, C. C., Wu, J. L., Lu, X. Q., Li, Y. S. : Cancer Det. Prev., 13, 79 (1988).

20) Luo, Y. Yoshizawa, T., Katayama, T.: Appl. Environ. Microbiol., 56, 2723 (1990).

21) Luo, Y., Yoshizawa, T., Yang, J. S., Zhang, S. Y., Zhang, B. J. : Mycotoxin Res., 8, 85 (1992).

22) Yoshizawa, T., Morooka, N.: J. Food. Hyg. Soc. Jpn., 15, 261 (1974).

23) Forsell, J. H., Jensen, R., Tai, J. H., Wilt, M., Lin, W. S., Pestka, J. J. : Food Chem. Toxicol., 25, 155 (1987).

24) Yoshizawa, T., Hosokawa, H.: J. Food Hyg. Soc. Jpn., 24, 413 (1983).

25) Kamimura, T., Nishijima, M., Yasuda, K., Saito, K., Ibe, A., Nagayama, T., Ushiyama, H., Naoi, Y.: J. Assoc. Off. Anal. Chem., 64, 1067 (1981).

26) Tanaka, T., Hasegawa, A., Matsuki, Y., Ueno, Y.: Food Add. Contam., 2, 259 (1985).

27) Scott, P. M. : J. AOAC Int., 79, 875 (1996).

28) Trucksess, M. W., Ready, D. E., Pender, M. K., Ligmond, C. A., Wood, G. E., Page, S. W. : J. AOAC Int., 79, 883 (1996). 